\title{
PENGARUH SUPERVISI KEPALA SEKOLAH TERHADAP KINERJA MENGAJAR GURU
}

\author{
Eko Sujadi, Muhd. Odha Meditamar, Martunus Wahab, Reni Putri Utama \\ Institut Agama Islam Negeri (IAIN) Kerinci \\ Coresponding Author, email: ekosujadi91@gmail.com
}

\begin{abstract}
ABSTRAK
Kinerja mengajar guru akan mempengaruhi keberhasilan siswa dalam belajar sehingga dapat meningkatkan mutu pendidikan. Salah satu faktor yang mempengaruhi kinerja mengajar adalah supervisi oleh kepala sekolah. Tujuan penelitian ini untuk mengetahui pengaruh supervisi kepala sekolah terhadap kinerja mengajar. Jenis penelitian yang digunakan dalam penelitian ini adalah penelitian ex-post facto. Berdasarkan tingkat eksplansinya (level of explanation) atau tingkat penjelasannya, penelitian ini dapat dikategorikan sebagai penelitian kuantitatif assosiatif. Populasi dalam penelitian ini sebanyak 52 guru Madrasah Tsanawiyah. Teknik pengambilan sampel yang digunakan dalam penelitian ini adalah total sampling. Instrumen pengumpulan data berbentuk angket yang telah melalui uji validitas dan reliabilitas. Pengujian hipotesis dengan menggunakan teknik regresi sederhana.

Hasil penelitian ini antara lain: 1) supervisi kepala sekolah tergolong tinggi; 2) kinerja mengajar guru tergolong tinggi; 3) terdapat pengaruh supervisi kepala sekolah terhadap kinerja mengajar guru. Kegiatan supervisi kepala sekolah tentunya memberikan pengaruh terhadap kinerja mengajar guru, sehingga kepala sekolah harus konsisten melaksanakan supervisi secara rutin. Guru juga hendaknya terus menunjukan performa mengajar yang baik sehingga dapat menghasilkan proses pembelajaran yang unggul dan berkualitas.
\end{abstract}

Kata Kunci: Supervisi, Kinerja Mengajar

\section{PENDAHULUAN}

Guru merupakan salah satu komponen manusiawi dalam proses pembelajaran yang ikut berperan dalam usaha pembentukan sumber daya manusia yang potensial di bidang pembangunan. Dalam hal ini, guru tidak semata-mata sebagai pengajar yang melakukan transfer ilmu pengetahuan, tetapi juga sebagai pendidik yang melakukan transfer nilai-nilai, memberikan pengarahan dan menuntun siswa dalam belajar. Kuantitas dan kualitas guru akan mempengaruhi 
keberhasilan siswa dalam belajar yang akan berujung pada peningkatan mutu pendidikan.

Pemerintah telah melakukan berbagai upaya untuk meningkatkan profesionalisme guru. Pengembangan profesi dan karir guru tersebut diarahkan untuk meningkatkan kompetensi dan kinerja guru dalam pelaksanaan proses pendidikan dan pembelajaran di kelas dan di luar kelas. Menurut Danim (2010:19) upaya peningkatan kompetensi dan profesionalitas ini harus sejalan dengan upaya untuk memberikan penghargaan, peningkatan kesejahteraan dan perlindungan terhadap guru.

Menurut Byars \& Rue (1991: 250) kinerja atau performance mengacu pada derajat tingkat penyelesaian tugas yang melengkapi pekerjaan seseorang. Hal ini mencerminkan seberapa baik seseorang dalam melaksanakan tuntutan suatu pekerjaan. Persyaratan penilaian kinerja harus memenuhi ukuran atau standar tertentu. Kinerja guru merupakan kemampuan seorang guru dalam melaksanakan tugas pembelajaran di madrasah dan bertanggung jawab atas peserta didik dibawah bimbingannya dengan meningkatkan prestasi belajar peserta didik. Oleh karena itu, kinerja guru itu dapat diartikan sebagai suatu kondisi yang menunjukkan kemampuan seorang guru dalam menjalankan tugasnya di madrasah serta mengambarkan adanya suatu perbuatan yang ditampilkan guru dalam atau selama melakukan aktivitas pembelajaran.

Di Indonesia, permasalahan mengenai kinerja mengajar guru masih terus terjadi. Seperti penelitian yang dipaparkan oleh Koswara, Suryana \& Triatna (2009), bahwa sertifikasi pada guru SMP yang berkorelasi sangat rendah terhadap peningkatan profesionalisme dan mutu pembelajaran. Selanjutnya Badrun (2011) mengemukakan bahwa kinerja sebagian besar guru profesional (pasca sertifikasi) belum baik. Dari 17 indikator yang diteliti, 7 indikator baik dan 10 indikator lainnya belum baik. Upaya atau aktivitas sebagian besar guru yang telah lulus sertifikasi dan telah menerima tunjangan profesi masih belum menggembirakan. Aktivitas di organisasi pendidikan dan sosial juga belum baik. Salah satu faktor yang mempengaruhi kinerja mengajar guru adalah kegiatan supervisi. Beberapa penelitian telah membuktikan pendapat tersebut (Amanda, Salam \& Saggaf, 2006; 
Ramadona \& Wibowo, 2016; Najemiah, 2017; Sudirjo \& Wulan, 2013; Lastriyani \& Herawan, 2013; Wildawati, Kandar \& Rini, 2015).

Supervisi mendorong guru menjadi lebih berdaya, dan situasi pembelajaran menjadi lebih baik, pengajaran menjadi efektif, guru menjadi puas dalam melaksanakan pekerjaannya. Dengan demikian sistem pendidikan dapat berfungsi sebagaimana mestinya. Dari proses supervisi ini, dapat diketahui kelemahan sekaligus keunggulan guru dalam melaksanakan pembelajaran, tingkat penguasaan kompetensi guru yang bersangkutan. Selanjutnya diupayakan solusi, pembinaan dan tindak lanjut tertentu sehingga guru dapat memperbaiki kekurangan yang ada sekaligus mempertahankan keunggulannya dalam melaksanakan pembelajaran.

Supervisi yang dilakukan oleh kepala sekolah akan memperoleh informasi tentang keberhasilan atau kegagalan guru dalam menjalankan tugas masing-masing. Penilaian tersebut pada dasarnya merupakan penilaian yang sistematik terhadap profesionalisme kerja guru terhadap taraf potensi kerja dalam upaya mengembangkan diri untuk kepentingan sekolah.

Berdasarkan permasalahan diatas, maka rumusan masalah dalam penelitian ini yakni bagaimana pengaruh kegiatan supervisi kepala sekolah terhadap kinerja mengajar?.

\section{METODE PENELITIAN}

Jenis penelitian yang digunakan dalam penelitian ini adalah penelitian $e x$ post facto. Berdasarkan tingkat eksplansinya (level of explanation) atau tingkat penjelasannya, penelitian ini dapat dikategorikan sebagai penelitian kuantitatif assosiatif. Populasi dalam penelitian ini sebanyaj 52 guru Madrasah Tsanawiyah. Teknik pengambilan sampel yang digunakan dalam penelitian ini adalah total sampling, di mana peneliti menjadikan seluruh populasi sebagai sampel, sehingga penelitian ini dapat juga disebut penelitian populasi. Instrumen pengumpulan data berbentuk angket yang dikembangkan oleh peneliti serta telah melalui uji validitas dan reliabilitas. Pengujian hipotesis dengan menggunakan teknik regresi 
sederhana. Sebelum dibuka uji regresi, peneliti terlebih dahulu melakukan uji persyaratan analisa meliputi uji normalitas dan linearitas.

\section{HASIL PENELITIAN}

Data yang diperoleh dari lapangan telah lulus uji normalitas dan linearitas. Pengujian normalitas data dengan menggunakan Kolmogorov - Smirnov dengan koreksi Liliefors, menggunakan ketetapan alpha $(\alpha)$ 0.05. Berdasarkan pengolahan data diperoleh hasil uji normalitas sebagai berikut.

\section{Tabel 1. Uji Normalitas Data}

\begin{tabular}{clcccc}
\hline No & \multicolumn{1}{c}{ Variabel } & N & Asymp. Sig & Ket. \\
\hline 1 & $\begin{array}{l}\text { Persepsi Guru Mengenai } \\
\text { Supervisi Kepala Sekolah }\end{array}$ & Kegiatan & 52 & 0,604 & Normal \\
\hline 2 & Kinerja Mengajar & 52 & 0,569 & Normal \\
\hline
\end{tabular}

Berdasarkan data pada Tabel 1 di atas, terlihat bahwa keseluruhan Asymp.Sig lebih besar dari 0.05, ini berarti data Supervisi Kepala Sekolah dan Kinerja Mengajar berdistribusi normal.

Uji lienaritas dalam penelitian ini akan dipaparkan pada tabel berikut ini :

Tabel 2. Uji Linearitas Data

\begin{tabular}{lccc}
\multicolumn{1}{c}{ Variabel } & $\begin{array}{c}\text { Deviation from } \\
\text { linearity }\end{array}$ & $\begin{array}{c}\text { Taraf } \\
\text { Signifikansi }\end{array}$ & Kesimpulan \\
\hline $\begin{array}{l}\text { Persepsi Guru Mengenai Kegiatan Supervisi Kepala } \\
\text { Sekolah Kinerja Mengajar }\end{array}$ & 0,963 & 0,05 & Normal \\
\hline
\end{tabular}

Berdasarkan tabel 2 di atas, diketahui nilai signifikansi 0,963 lebih besar dari 0,05. Dengan demikian data linear.

Berdasarkan verifikasi terhadap data penelitian, data yang diperoleh dari pengumpulan data sebanyak 52 data. Data penelitian ini meliputi dua variabel, yaitu: variabel kegiatan supervisi kepala sekolah dan kinerja mengajar. Deskripsi mengenai kegiatan supervisi kepala sekolah dapat dilihat pada Tabel berikut:

Tabel 3. Distribusi Frekuensi dan Kategori Skor Persepsi Guru Mengenai Kegiatan Supervisi Kepala Sekolah $(\mathbf{n}=52)$

\begin{tabular}{lcc}
\hline \multicolumn{1}{c}{ Kategori } & Frekuensi (f) & Persentase (\%) \\
\hline Sangat Tinggi (ST) & 5 & 9,615 \\
\hline Tinggi (T) & 41 & 78,846 \\
\hline Sedang (S) & 6 & 11,538 \\
\hline
\end{tabular}




\begin{tabular}{rcc}
\hline Rendah (R) & 0 & 0 \\
\hline Sangat Rendah (SR) & 0 & 0 \\
\hline Total & 52 & 100 \\
\hline
\end{tabular}

Dari Tabel di atas terlihat bahwa dari jumlah keseluruhan sampel yang berjumlah 52 guru, sebagian besar supervisi kepala sekolah berada pada kategori tinggi (T) dengan jumlah frekuensi 41 guru atau dapat dipersentasekan dengan nilai $78,846 \%$. Selanjutnya disusul pada kategori sedang (S) dan sangat tinggi (SR) memiliki frekuensi yang tidak jauh berbeda yaitu 6 dan 5 dengan persentase $11,538 \%$ dan 9,615\%. Pada keseluruhan indikator guru berada pada kategori tinggi (T), dengan skor maksimal yang dicapai sebesar 82. Skor terendah keseluruhan adalah 63 , skor total 3841 , rata-rata skor 73,86 . Berdasarkan skor tersebut diketahui bahwa untuk variabel supervisi kepala sekolah berada pada kategori tinggi.

Deskripsi mengenai kinerja mengajar dapat dilihat pada Tabel berikut:

Tabel 4. Distribusi Frekuensi dan Kategori Skor Tingkat Kinerja Mengajar (n=52)

\begin{tabular}{lcc}
\hline \multicolumn{1}{c}{ Kategori } & Frekuensi (f) & Persentase (\%) \\
\hline Sangat Tinggi (ST) & 8 & 15,384 \\
\hline Tinggi (T) & 44 & 84,615 \\
\hline Sedang (S) & 0 & 0 \\
\hline Rendah (R) & 0 & 0 \\
\hline Sangat Rendah (SR) & 0 & 0 \\
\hline \multicolumn{1}{r}{ Total } & 52 & 100 \\
\hline
\end{tabular}

Dari keseluruhan sampel yang berjumlah 52 guru, sebagian besar kinerja mengajar berada pada kategori tinggi (T) dengan jumlah frekuensi 44 guru yang dapat dipersentasekan dengan nilai 84,615\%. Kategori sangat tinggi (ST) dengan jumlah frekuensi 8 guru atau dapat dipersentasekan dengan nilai 15,384\%. Secara keseluruhan pada semua indikator, guru berada pada kategori tinggi $(\mathrm{T})$, dengan skor maksimal yang dicapai sebesar 152. Skor terendah yakni 119, skor total sebesar 6951, rata-rata skor 165,5.

Setelah uji persyaratan analisis dilakukan, selanjutnya dilaksanakan pengujian hipotesis. Adapun hipotesis dalam penelitian ini, yaitu: “Terdapat 
pengaruh persepsi guru mengenai kegiatan supervisi kepala sekolah terhadap kinerja mengajar". Untuk menjawab hipotesis di atas maka dilakukan analisis korelasi antara kegiatan supervisi kepala sekolah terhadap kinerja mengajar. Uji keberartian koefisien korelasi disajikan pada Tabel berikut ini.

Tabel 5. Hasil Analisis Korelasi Variabel Persepsi Guru Mengenai Kegiatan Supervisi

\begin{tabular}{lccrrr}
\multicolumn{7}{c}{ Kepala Sekolah } & Terhadap Kinerja Mengajar & & \\
\hline Model & $\mathrm{R}$ & R Square & Adjusted R Square & & Std. Error of the Estimate \\
\hline 1 & $0.314^{\mathrm{a}}$ & .099 & & .081 & 8.38599 \\
\hline
\end{tabular}

Pada Tabel di atas terlihat bahwa nilai $r$ sebesar 0.314, yang menunjukkan koefisien korelasi negatif antara persepsi guru mengenai kegiatan supervisi kepala sekolah terhadap kinerja mengajar. Nilai r Square sebesar 0,099. Hal ini menunjukkan bahwa persepsi guru mengenai kegiatan supervisi kepala sekolah berpengaruh terhadap kinerja mengajar. Setelah diketahui maka selanjutnya uji signifikansi pada Tabel berikut:

Tabel 6. Hasil Ringkasan Anova untuk Uji Signifikansi

\begin{tabular}{lrrrrr}
\hline Model & Sum of Squares & Df & Mean Square & F & Sig. \\
\hline Regression & 385.450 & 1 & 385.450 & 5.481 & $0.023^{\mathrm{a}}$ \\
\hline Residual & 3516.242 & 50 & 70.325 & & \\
\hline Total & 3901.692 & 51 & & & \\
\hline \multicolumn{7}{c}{ Tabel tersebut telah menunjukkan bahwa } & 0,023 lebih kecil dari 0,05 maka
\end{tabular}

kinerja mengajar memiliki pengaruh terhadap kegiatan supervisi kepala sekolah.

Selanjutnya untuk mengetahui hasil analisis regresi sederhana dapat dilihat pada

Tabel berikut:

Tabel 7. Hasil Analisis Regresi Sederhana Persepsi Guru Mengenai Kegiatan Supervisi Kepala Sekolah terhadap Kinerja Mengajar

\begin{tabular}{|c|c|c|c|c|c|}
\hline \multirow[t]{2}{*}{ Model } & \multicolumn{2}{|c|}{ Unstandardized Coefficients } & $\begin{array}{c}\text { Standardized } \\
\text { Coefficients }\end{array}$ & \multirow[t]{2}{*}{$\mathrm{T}$} & \multirow[t]{2}{*}{ Sig. } \\
\hline & $\mathrm{B}$ & Std. Error & Beta & & \\
\hline (Constant) & 98.333 & 15.3 & & 6.422 & .000 \\
\hline
\end{tabular}

Dari Tabel diketahui $\mathrm{t}_{\text {hitung }}$ adalah 2.341 pada taraf signifikan 0,023 , maka Ha diterima, artinya koefisien regresi signifikan. Dapat disimpulkan bahwa terdapat pengaruh kinerja mengajar terhadap persepsi guru mengenai kegiatan supervisi kepala sekolah. 


\section{PEMBAHASAN}

Berdasarkan pengujian hipotesis untuk mengetahui pengaruh kegiatan supervisi kepala sekolah terhadap kinerja mengajar diperoleh hasil regresi linear $\mathrm{R}$ square sebesar 0,099 yang menunjukkan bahwa kegiatan supervisi kepala sekolah berpengaruh terhadap kinerja mengajar. Dilihat dari F hitung 5,481 dengan sig. $0,023<0,05$ maka kegiatan supervisi memiliki pengaruh terhadap kinerja mengajar. Kinerja mengajar yang baik sangat dibutuhkan oleh setiap guru guru. Modal kinerja mengajar yang berada pada kategori tinggi ini seharusnya tetap dijaga atau ditingkatkan lagi. Hal ini bertujuan untuk menjaga nilai, kualitas dan kepercayaan masyarakat terhadap sekolah.

Kinerja mengajar guru berpengaruh terhadap beberapa variabel keberhasilan lainnya. Dengan kata lain, semakin baik kinerja guru maka aspekaspek lainnya juga akan meningkat. Penelitian membuktikan bahwa kinerja guru berpengaruh terhadap motivasi belajar siswa (Raisyifa, \& Sutarni, 2016; Widoyoko \& Rinawati, 2012; Nugraha, 2017; Indrawati, Lestar \& Lubis, 2015). Kinerja mengajar juga berpengaruh terhadap prestasi belajar siswa (Armoko \& Sumarjo, 2015; Asmawati, 2017; Lestari, 2016).

Mengingat pentingnya variabel ini, maka setiap guru di Indonesia harus berkinerja agar tujuan pendidikan nasional dapat tercapai. Namun pada kenyataannya permasalahan rendahnya kinerja masih terus terjadi, baik pada level pendidikan dasar hingga pendidikan tinggi. Masih ditemukan pendidik yang tidak menjalankan tugas pokok dan fungsinya sesuai dengan indikator kinerja. Sudjana et al (2004: 107) mengemukakan indikator kinerja guru, yaitu: a) Menguasai bahan yang akan diajarkan. b) Mengelola program belajar mengajar. c) Mengelola kelas. d) Menggunakan media/sumber pelajaran. e) Menguasai landasan- landasan kependidikan. f) Mengelola interaksi belajar mengajar. g) Menilai prestasi siswa. h) Mengenal fungsi dan program bimbingan dan penyuluhan. i) Mengenal dan menyelenggarakan administrasi sekolah. j) Memahami prinsip-prinsip dan menafsirkan hasil-hasil penelitian. 
Kinerja mengajar dipengaruhi oleh beberapa faktor, salah satunya adalah kegiatan supervisi yang dilakukan oleh kepala sekolah. Supervisi pendidikan bertujuan untuk meningkatkan kemampuan guru melalui kegiatan refleksi atas praktik yang mereka lakukan, untuk belajar mengenai apa yang mereka lakukan dan untuk pengembangan profesionalitas (Sergiovanni \& Starratt, 2007). Efektivitas supervisi tergantung pada kepercayaan, kerjasama, atmosfir dan komunikasi yang positif antara supervisor dan yang disupervisi (Ozdemir \& Yirci, 2015). Hasil penelitian ini mendukung beberapa penelitian yang telah dilakukan oleh peneliti terdahulu (Amanda, Salam \& Saggaf, 2006; Ramadona \& Wibowo, 2016; Najemiah, 2017; Sudirjo \& Wulan, 2013; Lastriyani \& Herawan, 2013; Wildawati, Kandar \& Rini, 2015).

Mengingat pentingnya pelaksanaan supervisi, maka kepala sekolah diharapkan mampu melaksanakan supervisi sebaik mungkin, bukan untuk mencari-cari kesalahan namun lebih bersifat pada pembinaan. Menurut Maralih (2004), tugas pemimpin sebagai supervisor berfungsi membantu, mendorong, menstimulasi tiap anggota untuk bekerja bersama. Seorang supervisor dalam melakukan dalam melakukan tanggung jawabnya, ia harus mampu mengembangkan potensi kreativitas dari orang yang dibina melalui cara mengikutsertakan orang lain untuk berpartisipasi bersama. Supervisor dapat memberikan saran secara terbuka tetapi bersahabat tentang masalah-masalah yang dikemukakan dalam penilaian, dan guru harus bersifat terbuka untuk menerimannya.maka akan terjadi proses saling memperkaya antara guru supervisor dalam usaha untuk berkembang dalam melaksanakan tugas pendidkan mereka. 


\section{PENUTUP}

Berdasarkan hasil penelitian di atas, maka dapat disimpulkan bahwa: 1) kegiatan supervisi kepala sekolah tergolong tinggi; 2) kinerja mengajar guru tergolong tinggi; 3) terdapat pengaruh kegiatan supervisi kepala sekolah terhadap kinerja mengajar guru. Kegiatan supervisi yang dilakukan kepala sekolah tentunya memberikan pengaruh terhadap kinerja mengajar guru, dengan demikian kepala sekolah dapat terus melaksanakan supervisi secara rutin. Selain itu guru juga hendaknya terus menunjukan performa mengajar yang baik sehingga dapat menghasilkan proses pembelajaran yang unggul dan berkualitas.

\section{DAFTAR REFERENSI}

Abdurrahman, Fatoni. 2006, Manajemen Sumber Daya Manusia. Jakarta : PT Raneka Cipta.

Amanda, Mentari Ocvilia., Salam, Rudi., \& Saggaf, Said. 2016. Pengaruh Supervisi Kepala Sekolah Terhadap Kinerja Guru di SMK Negeri 1

Bungoro Kabupaten Pangke. Disajikan pada seminar nasional "Pendidikan Ilmu-Ilmu Sosial Membentuk Karakter Bangsa Dalam Rangka Daya Saing Global” Kerjasama Fakultas Ilmu Sosial Universitas Negeri Makassar dan Himpunan Sarjana Pendidikan Ilmu-ilmu Sosial Indonesia di Grand Clarion Hotel, Makassar, 29 Oktober 2016

Armoko, Taufik Windi \& Sumarjo. 2015. Pengaruh Kinerja Mengajar Guru Terhadap Prestasi Belajar Kejuruan Siswa Program Keahlian Teknik Gambar Bagunan di SMK N Negeri 1 Seyegan. E Journal Pendidikan Teknik Sipil dan Perencanaan, 3 (1): 1-5.

Asmawati. 2017. Pengaruh Kinerja Guru Terhadap Hasil Belajar Siswa Sekolah Dasar di Kecamatan Larompong Kabupaten Luwu. Pedagogy, 2 (1): 4453.

Badrun Kartowagiran. 2011. Kinerja Guru Profesional (Guru yang Sudah Lulus Sertifikasi Guru dan Sudah Mendapat Tunjangan Profesi) di Kabupaten Sleman Yogyakarta. Laporan hasil penelitian tidak diterbitkan. Yogyakarta: Pusat Kajian Pengembangan Sistem Pengujian dan Pusat Kajian Pendidikan Dasar dan Menengah, Lembaga Penelitian Universitas Negeri Yogyakarta. 
Byars, L. L., \& Rue, L. W., 1991. Human resources management. (3 ${ }^{\text {rd }}$ ed). Boston: Irwin Inc

Danim, Sudarwan. 2010. Profesionalisasi dan Etika Profesi Guru. Bandung : Alfabeta.

Harahap, Baharuddin. 1983. Supervisi Pendidikan. Jakarta PT. Ciawijaya.

Indrawati., Lestari, Rena., Lubis, Riki Riharji. 2015. Kinerja Guru Terhadap Motivasi Belajar Siswa Madrasah Aliyah Kepenuhan Kabupaten Rokan Hulu. E Journal Mahasiswa Prodi Biologi Univ. Pasir Pangaraian, 1 (1): $1-5$.

Indri Lastriyani \& Endang Herawan. 2013. Pengaruh Supervisi Kepala Sekolah dan Kompensasi Terhadap Kinerja Mengajar Guru. Jurnal Adminisistrasi Pendidikan, 27 (1): 96-106.

Koswara. Deni., Suryana, Asep., \& Triatna, Cepi. 2009. Studi Dampak Program Sertifikasi Guru Terhadap Peningkatan Rofesionalisme dan Mutu di Jawa Barat. Laporan hasil penelitian tidak diterbitkan. Bandung: Universitas Pendidikan Indonesia.

Maralih. 2004. Peranan Supervisi dalam Peningkatan Kualitas Pendidikan. Jurnal Qathrunâ, 1 (1): 179-192.

Mitchell, T. R., \& Larson, J. R., jr., 1987. People in organizations, an introduction to organizational behavior ( $3^{\text {rd }}$ ed). Singapore : Mc Graw Hill Book Company.

Mukhtar \& Iskandar. 2009. Orientasi Baru Supervisi Pendidikan. Jakarta: Gaung Persada.

Mustofa, Asf. 2013. Supervisi Pendidikan. Yogjakarta : Ar-Ruzz Media.

Najemiah, Andi. Pengaruh Supervisi dan Sertifikasi Terhadap Kinerja Guru (Studi Kasus Pada Sekolah Menengah Pertama Negeri 7 Palu). Jurnal Katalogis, 5 (6): 10-19

Nugraha, Yogi. 2017. Pengaruh Kinerja Guru PKN dan Iklim Belajar Terhadap Motivasi Belajar Siswa. Wahana Karya Ilmiah Pendidikan, 1 (1): 26-39.

Ozdemir, T. Y., \& Yirci, R. 2015. A Situational Analysis of Educational Supervision in the Turkish Educational System. Educational Process: International Journal, 4 (1-2), 56-70.

Purbasari, Margi. 2015. Pengaruh Supervisi Akademik Terhadap Kinerja Mengajar Guru di Sekolah Dasar. Journal of Elementary Education, 4 (1): 46-53. 
Purwanto, Ngalim. 2006. Administrasi \& Supervisi Pendidikan. Bandung: Remaja Rosdakarya

Raisyifa, Destia Nur., \& Sutarni, Nani. 2016. Pengaruh kinerja mengajar guru terhadap motivasi belajar siswa. Jurnal Pendidikan Manajemen Perkantoran, 1 (1): 90-98.

Ramadona, Mohammad \& Wibowo, Rian. Pengaruh Supervisi Kepala Sekolah Terhadap Kinerja Guru di SMP K 1 Penabur Pasar Baru Jakarta Pusat. Research and Development Journal of Education, 3 (1): 27-34.

Sahertian, Piet A. 2008. Konsep Dasar Teknik Supervisi Pendidikan Dalam Rangka Pengembangan Sumber Daya Manusia. Jakarta : Rineka Cipta.

Sergiovanni, T. J., \& Starratt, R. J. 2007. Supervision: A redefinition. New York, NY: McGraw-Hill.

Slameto. Permasalahan-Permasalahan Terkait Dengan Profesi Guru SD. Scholaria, 4 (3): 1-12

Sri Lestari. 2016. Pengaruh Kepemimpinan Kepala Sekolah dan Kinerja Guru Terhadap Prestasi Siswa. Satya Widya, 32 (2): 127-132.

Sudirjo, Frans \& Wulan, Deriana Rekno. 2013. Pengaruh Supervisi dan Kepemimpinan Kepala Sekolah Terhadap Motivasi Untuk Peningkatan Kinerja Guru (Studi Empiris di SMP Negeri 33 Kota Semarang). Jurnal Serat Acitya, 2 (3): 18-26.

Susanto, Hary. Faktor-Faktor Yang Mempengaruhi Kinerja Guru Sekolah Menengah Kejuruan. Jurnal Pendidikan Vokasi, 2 (2): 197-212.

Widoyoko, S. Eko Putro \& Rinawati, Anita. 2012. Pengaruh Kinerja Guru Terhadap Motivasi Belajar Siswa. Cakrawala Pendidikan, (2): 278-289.

Wildawati., Kandar, Supomo., \& Rini, Riswanti. 2015. Pengaruh Supervisi Akademik dan Kepemimpinan Kepala Sekolah Terhadap Kinerja Guru SMP Negeri di Kecamatan Sungkai Utara Kabupaten Lampung Utara. Journal of Elementary Education, 14 (1): 1-10. 